\title{
Gambaran pola asupan makanan pada remaja di Kabupaten Bolaang Mongondow Utara
}

\author{
${ }^{1}$ Farah S. Mokoginta \\ ${ }^{2}$ Fona Budiarso \\ ${ }^{3}$ Aaltje E. Manampiring
}

\author{
${ }^{1}$ Kandidat Skripsi Fakultas Kedokteran Universitas Sam Ratulangi Manado \\ ${ }^{2}$ Bagian Kimia Fakultas Kedokteran Universitas Sam Ratulangi Manado \\ Email: mokogintafarah@gmail.com
}

\begin{abstract}
Food pattern is an important criteria that affecting the nutrition and to fulfill the need of balanced nutrition. Adolescents are often indicated as vulnerable because of their massive growth and development as well as their highly needs of energy to do various of physical activities. The insufficiency of food pattern can easily affecting due to their imbalanced growth and development, and increase higher risk prior to many chronic diseases regarding their adultery life. The importance of balanced food pattern and nutrition intake in adolescence and there has been no amount of research applied for North Bolaang Mongondow province attract the writer to do this research. The main purpose of this research is to know the pattern of food and nutrition consumption in adolescent. This research is a descriptive study with the design of cross sectional. The results showed the majority of food consumed by adolescents are rice (90\%), fishes (77,5\%), tofu $(47,5 \%)$, water spinach $(57,5 \%)$, banana $(32,5 \%)$, milk $(47,5 \%)$, bread $(47,5 \%)$, and colacola $(30 \%)$ for $>1$ /day frequent. The amount of energy consumption is severely insufficient $(97,5 \%)$, carbohydrate consumption is $<70 \%$ RDA $(95 \%)$, protein is $<70 \%$ RDA $(77,5 \%)$, and total fat is $<70 \%$ RDA $(77,5 \%)$. Conclusion: The food pattern in adolescent commonly has less various of menu where the average of frequency is $>1$ /day with minimum amount of food and incomplete of consumption each of time.
\end{abstract}

Keywords: food pattern, food consumption, nutrition, adolescent

\begin{abstract}
Abstrak: Pola makan merupakan kebiasaan penting yang dapat mempengaruhi keadaan gizi dan untuk memenuhi kebutuhan gizi seimbang. Usia remaja adalah usia rentan gizi karena tumbuh kembang yang pesat dan dibutuhkan energi yang cukup untuk melakukan beragam aktivitas fisik. Jika pola asupan buruk, akan berdampak pada pertumbuhan dan perkembangan yang tidak optimal, serta lebih rentan terhadap penyakit-penyakit kronis di masa dewasa. Pentingnya pola asupan makan yang seimbang pada remaja serta belum adanya penelitian yang dilakukan di daerah Bolaang Mongondow Utara membuat penulis tertarik untuk melakukan penelitian ini. Tujuan umum penelitian ini adalah untuk mengetahui gambaran pola asupan makanan pada remaja di Kabupaten Bolaang Mongondow Utara. Jenis penelitian ini bersifat deskriptif dengan menggunakan desain potong lintang (cross sectional). Hasil penelitian ini menunjukan bahwa kategori terbanyak yang dikonsumsi adalah beras(90\%), ikan segar (77,5\%), tahu $(47,5 \%)$, kangkung $(57,5 \%)$, pisang $(32,5 \%)$, susu $(47,5 \%)$, roti $(47,5 \%)$, dan cola-cola $(30 \%)$ untuk frekuensi $>1 \mathrm{x} /$ hari. Tingkat kecukupan energi didapati sangat kurang $(97,5 \%)$, kecukupan karbohidrat $<70 \%$ AKG (95\%), protein $<70 \%$ AKG $(77,5 \%)$, dan lemak $<70 \%$ AKG $(77,5 \%)$. Simpulan: Pola makan remaja umumnya kurang bervariasi dengan frekuensi rata-rata $>1 \mathrm{x} / \mathrm{hari}$ namun dengan jumlah yang sedikit dan dikonsumsi tidak lengkap tiap kali makan. Tingkat kecukupan gizi remaja $<70 \%$ AKG menandakan bahwa asupan energi dari sumber karbohidrat, protein, lemak sangat kurang.
\end{abstract}

Kata kunci: pola makan, pola konsumsi, nutrisi, asupan gizi, remaja. 
Pola makan dapat mempengaruhi keadaan gizi, dan sangat penting untuk memenuhi kebutuhan gizi seimbang sehari-hari. Tercapainya gizi seimbang dapat bermanfaat untuk mencegah terjadinya masalah kesehatan dan gizi. ${ }^{1,2,3}$

Negara berkembang umumnya mempunyai masalah gizi kurang, dimana $80 \%$ energi makanan yang dikonsumsi oleh masyarakat berasal dari karbohidrat. ${ }^{1,4}$

Di Indonesia, masalah gizi yang sedang dihadapi adalah masalah gizi kurang namun mulai bermunculan masalah gizi lebih secara bersamaan (double burden). Masalah yang lebih besar lagi yaitu masalah gizi pada kelompok usia tertentu seperti remaja yang bila dibiarkan akan diteruskan ke generasi berikutnya (intergenerational impact). ${ }^{5,6}$

Umumnya kelompok usia remaja, merupakan periode rentan gizi karena peningkatan pertumbuhan fisik dan perkembangan yang pesat. Selain itu pada remaja dibutuhkan energi yang cukup untuk melakukan aktivitas fisik yang beragam. ${ }^{1,7}$ Pola asupan yang buruk akan berdampak pada pertumbuhan dan perkembangan yang tidak optimal, serta lebih rentan terhadap penyakit-penyakit kronis seperti penyakit kardiovaskular, kanker, dan osteoporosis di masa dewasa. ${ }^{6,8}$

Penelitian sebelumnya menunjukkan bahwa puncak pertumbuhan remaja puteri di Bangladesh tertunda dikarenakan mengonsumsi lebih sedikit kalori dibandingkan kelompok remaja laki-laki. Tingkat konsumsi kalori juga dipengaruhi oleh usia. Semakin tinggi kelompok usia maka semakin rendah konsumsi kalorinya. ${ }^{9}$

Kelompok remaja obesitas dan kelompok non obesitas terbukti memiliki perbedaan yang bermakna pada frekuensi makan, pola konsumsi makanan cepat saji, pola konsumsi kudapan atau makanan ringan, serta tingkat konsumsi energi, karbohidrat, protein, dan lemak. ${ }^{10}$

Di Sulawesi Utara, sebanyak 7,4 persen remaja memiliki status gizi overweight, dan 2,6 persen remaja memiliki status gizi obese. ${ }^{11}$ Hal yang serupa juga didapati di kota Bitung dimana status gizi remaja diatas normal serta didapati pola makan remaja yang berlebihan. $^{12}$

Kabupaten Bolaang Mongondow Utara adalah daerah yang jauh berbeda dengan kota Bitung. Daerah ini masih dalam tahap pembangunan. ${ }^{13}$ Mayoritas mata pencaharian adalah petani dan nelayan dengan pendapatan kurang. ${ }^{13,14}$

Pentingnya pola asupan makan yang seimbang pada remaja serta belum adanya penelitian yang dilakukan di daerah Bolaang Mongondow Utara membuat penulis tertarik dan merasa perlu untuk melakukan penelitian ini.

\section{METODE PENELITIAN}

Jenis penelitian ini bersifat deskriptif dengan menggunakan desain potong lintang (cross sectional). Penelitian ini dilaksanakan di Kabupaten Bolaang Mongondow Utara Kecamatan Bolangitang Barat dari bulan September 2016 sampai dengan November 2016. Populasi dalam penelitian ini adalah remaja di Kabupaten Bolaang Mongondow Utara. Subjek dalam penelitian ini berjumlah 40 responden dan ditentukan berdasarkan kriteria inklusi. Penarikan sampel diambil secara simple random sampling. Adapun kriteria Inklusi yaitu:

a. Remaja yang memiliki usia 10-19 tahun

b. Bersedia menjadi responden dan menandatangani informed concent

c. Bersedia melakukan wawancara secara langsung

Kriteria Eksklusi ialah:

a. Remaja yang tidak bersedia menjadi responden

b. Tidak berada ditempat saat pelaksanaan penelitian

c. Berumur $>19$ tahun

Penelitian menggunakan FFQ (Food Frequency Questionnaire), Food Recall 24 jam, Food Model, dan Alat Tulis Menulis. Hasil kuisioner selanjutnya di analisis kemudian di olah dalam bentuk tabulasi. 
Asupan energi (karbohidrat, lemak, protein) dihitung rata-rata menggunakan program software Nutrisurvey. Jumlah selanjutnya dibandingkan dengan AKG (Angka Kecukupan Gizi). Hasil keduanya kemudian disajikan secara deskriptif.

HASIL PENELITIAN DAN BAHASAN Jenis Kelamin

Tabel 1.1 Distribusi jenis kelamin responden

\begin{tabular}{cccll}
\hline \multirow{2}{*}{ No. } & \multicolumn{2}{c}{ Jenis Kelamin } & Jumlah \\
\cline { 4 - 5 } & & n & \% \\
1. & Laki-laki & 26 & 65 \\
2. & Perempuan & 14 & 35 \\
\cline { 1 - 1 } & Total & 40 & 100 \\
\hline
\end{tabular}

Hasil penelitian menunjukkan mayoritas jenis kelamin subjek penelitian adalah laki-laki dengan jumlah 26 orang (65\%), dan sampel perempuan sebanyak 14 orang $(35 \%)$.

\section{Umur}

Tabel 1.2 Distribusi Umur Responden

\begin{tabular}{cccccc}
\hline No. & Kategori & \multicolumn{2}{c}{ Laki-laki } & \multicolumn{2}{c}{ Perempuan } \\
\cline { 3 - 6 } & Umur & n & \% & n & \% \\
\hline 1. & $10-12$ & 3 & 11,5 & 2 & 14,3 \\
2. & $13-14$ & 8 & 30,8 & 3 & 21,4 \\
2. & $15-18$ & 11 & 42,3 & 8 & 57,1 \\
2. & $19-24$ & 4 & 15,4 & 1 & 7,1 \\
& Total & 26 & 100 & 14 & 100 \\
\hline
\end{tabular}

Berdasarkan hasil penelitian, kategori terbanyak adalah umur 15-18 tahun dengan jumlah 11 orang laki-laki $(42,3 \%)$ dan 8 orang perempuan $(57,1 \%)$.

\section{Analisis Pola Makan}

Pola asupan makan / konsumsi makan dapat dilihat berdasarkan hasil analisis kuisioner food frequency dan food recall 1 hari dimana didapatkan informasi berupa jenis, jumlah, dan frekuensi dari bahan makanan yang di konsumsi responden. ${ }^{15}$ Gambaran pola asupan makan dapat menjadi ciri khas untuk suatu kelompok masyarakat tertentu juga menjadi salah satu indikator penting untuk melihat tercukupinya kebutuhan gizi. ${ }^{1,16}$ Jenis makanan mewakili variasi bahan makanan yang jika dimakan, dicerna, dan diserap tubuh akan menghasilkan paling sedikit satu macam nutrien. Frekuensi makanan menunjukkan jumlah berapa kali makanan tersebut di konsumsi. ${ }^{17}$

Makanan pokok mengandung karbohidrat yang sering dikonsumsi dan telah menjadi bagian dari budaya makan berbagai etnik di Indonesia sejak lama. ${ }^{18}$ Berdasarkan hasil penelitian, seluruh remaja mengkonsumsi nasi sebagai makanan pokok. Nasi dikonsumsi dengan frekuensi lebih dari $1 \mathrm{x}$ setiap harinya. Terpilihnya nasi sebagai pilihan utama dikarenakan nasi merupakan makanan pokok yang mudah diperoleh dan dikonsumsi oleh keluarga secara turun temurun. Kedua hal ini merupakan faktor penentu kebiasaan makan seseorang. ${ }^{19}$ Hasil ini berhubungan dengan sumber mata pencaharian penduduk Bolaang Mongondow Utara, dimana mayoritas pekerjaan penduduk $(60 \%)$ mengandalkan sektor pertanian dan kelautan. ${ }^{20}$ Sumber energi juga didapat dari konsumsi mie, singkong, jagung, dan roti putih meskipun jumlahnya lebih sedikit dan dikonsumsi dengan frekuensi yang bervariasi. Sereal adalah makanan pokok yang paling sedikit dikonsumsi. Sereal jarang dikonsumsi dimana frekuensinya hanya $1-3 x$ dalam sebulan. Hal ini disebabkan karena jenis sereal bukan merupakan bagian dari budaya makan orang daerah. Hal ini ditunjang dengan pendapat Sediaoetama, dimana budaya daerah setempat adalah faktor yang dapat menentukan kebiasaan makan penduduk di daerah tersebut. ${ }^{4}$ Pedoman umum gizi seimbang menganjurkan untuk membiasakan mengkonsumsi lauk pauk yang tinggi protein baik yang berasal dari protein hewani, dan protein nabati. ${ }^{18}$ Untuk kategori makanan sumber hewani, responden paling banyak mengkonsumsi ikan segar. Ikan segar di konsumsi >1x setiap harinya. Hal ini dapat dikarenakan mayoritas pekerjaan di sektor kelautan seperti nelayan dan lingkungan yang berada di pesisir laut. ${ }^{14}$ Sumber lainnya juga 
adalah ikan asin dan udang. Sumber hewani non bahari adalah daging ayam dan daging sapi. Daging sapi lebih jarang dikonsumsi yaitu1-3x setiap bulan. Berbeda dengan daging ayam yang dikonsumsi lebih sering yaitu 1-3x setiap minggunya. Hal ini disebabkan daging ayam cenderung lebih murah untuk dikonsumsi sesuai dengan status ekonomi penduduk. Umumnya daging sapi dikonsumsi hanya pada acara tertentu bukan sebagai lauk harian. ${ }^{13,14}$ Sumber hewani seperti daging-dagingan bukan hanya menambah asupan protein, namun juga asupan lemak. Penelitian di daerah Yogyakarta menunjukkan bahwa sumber hewani yang paling banyak di konsumsi adalah daging ayam dan sapi dengan mayoritas usia reproduktif. Hal ini menyebabkan tingkat asupan lemak yang tinggi. $^{18,21}$

Sumber hewani lainnya adalah telur ayam, daging kambing, nugget, dan sossis. Nugget dan sossis adalah yang paling jarang di konsumsi yaitu 2-3x/bulan. Masih melekatnya budaya di daerah penelitian menyebabkan masyarakat belum terbiasa mengkonsumsi jenis makanan western seperti nugget dan sosis sebagai menu harian. ${ }^{14}$ Selera masyarakat dalam memilih makanan cenderung pada yang tradisional karena lebih terbiasa dan dianggap lebih mengenyangkan. Hal ini akan memberikan rasa puas mengkonsumsi makanan tersebut. ${ }^{4}$

Sumber hewani mempunyai asam amino yang lebih lengkap dan mempunyai mutu zat gizi yaitu protein, vitamin dan mineral lebih baik karena kandungan zatzat gizi tersebut lebih banyak dan mudah diserap tubuh. Tetapi sumber hewani mengandung tinggi kolesterol (kecuali ikan) dan lemak. Lemak dari daging sapi dan unggas lebih banyak mengandung lemak jenuh. Kolesterol dan lemak jenuh diperlukan tubuh terutama pada anak-anak tetapi perlu dibatasai asupannya pada orang dewasa. ${ }^{18}$

Sumber makanan kacang-kacangan juga mengandung nutrisi yang penting yaitu protein nabati. Tahu adalah yang terbanyak dikonsumsi oleh responden dimana umumnya dikonsumsi harian dengan jumlah $>1 \mathrm{x}$ setiap harinya. Sumber protein nabati lainnya yaitu tempe, kacang tanah, dan kacang hijau. Tempe dan kacang tanah paling banyak di konsumsi dalam 1x setiap harinya. Kacang hijau dikonsumsi setiap minggu sejumlah 1-3 kali. Sumber protein nabati mempunyai keunggulan mengandung proporsi lemak tidak jenuh yang lebih banyak dibanding sumber hewani. Sumber protein nabati juga mengandung isoflavon, yaitu kandungan fitokimia yang berfungsi mirip hormon estrogen dan antioksidan serta antikolesterol. Selain itu konsumsi kedele dan tempe dapat menurunkan kolesterol dan meningkatkan sensitifitas insulin dan produksi insulin sehingga dapat mengendalikan kadar kolesterol dan gula darah. Kelemahannya adalah kualitas protein dan mineral yang dikandung oleh sumber protein nabati lebih rendah dibanding sumber protein hewani. Oleh karena itu, guna mencapai gizi yang seimbang diperlukan konsumsi bersama makanan-makanan lainnya setiap hari, agar jumlah dan kualitas zat gizi yang diperoleh lebih sempurna. ${ }^{18}$

Kangkung adalah yang terbanyak di konsumsi. Dalam 1 hari responden mengkonsumsi kangkung $>1$ kali. Sayuran yang juga dikonsumsi adalah kacang panjang, bayam, dan daun singkong. Ketiga jenis sayuran ini dikonsumsi $>1 \mathrm{x}$ setiap hari. Timun dan buncis lebih sedikit di konsumsi. Sebagian remaja mengkonsumsi timun dan buncis $>1 \mathrm{x}$ setiap hari. Sementara sawi hijau di konsumsi 1-3x dalam sebulan. Sayuran yang paling sedikit dan paling jarang di konsumsi adalah brokoli. Brokoli di konsumsi oleh sedikit remaja selama beberapa kali saja dalam 1 bulan.

Berdasarkan data riset kesehatan, konsumsi sayuran untuk umur di atas 10 tahun masih rendah yaitu sebesar $36,7 \% .^{10}$ Padahal sayuran dan buah-buahan merupakan sumber berbagai vitamin, mineral dan serat pangan yang berperan 
sebagai antioksidan. Konsumsi buahbuahan dan sayuran yang cukup turut berperan dalam menjaga kenormalan tekanan darah, gula darah, dan kolestrol. Konsumsi sayur dan buah yang cukup juga menurunkan resiko sembelit, obesitas, dan resiko untuk penyakit tidak menular lainnya. $^{10,18}$ Badan Kesehatan Dunia (WHO) secara umum menganjurkan konsumsi sayuran dan buah-buahan untuk hidup sehat sejumlah $400 \mathrm{~g}$ perorang perhari, yang terdiri dari $250 \mathrm{~g}$ sayur (setara dengan $21 / 2$ porsi atau $21 / 2$ gelas sayursetelah dimasak dan ditiriskan) dan 150 g buah. $^{18}$

Buah apel dan pisang adalah yang paling banyak di konsumsi remaja di daerah penelitian. Rata-rata remaja mengkonsumsi apel setiap bulannya 1-3x sedangkan pisang di konsumsi $>1 \mathrm{x}$ setiap harinya. Hal ini dapat disebabkan karena pisang merupakan buah yang lebih gampang di peroleh dibandingkan apel baik dari segi harga maupun ketersediaannya. Jenis buah lain adalah pepaya, mangga, dan jeruk. Frekuensi konsumsi pepaya umumnya bervariasi. Sedangkan jenis buah mangga dan jeruk jarang. Konsumsi ratarata buah mangga paling banyak mencapai 1-3x tiap bulannya. Sedangkan jeruk lebih sering dikonsumsi yaitu rata-rata mencapai $1-3 x$ setiap minggu. Umumnya remaja mengkonsumsi buah dengan dimakan langsung tanpa pengolahan lanjut. Dari hasil penelitian, remaja cenderung hanya mengkonsumsi sedikit variasi buah-buahan, dimana mereka hanya mengkonsumsi 1-2 jenis buah saja. Hasil yang sama juga ditemukan di penelitian yang dilakukan pada remaja SMA N 1 Pekanbaru. ${ }^{22}$

Konsumsi buah dan sayur di Indonesia memang masih tergolong rendah. Berdasarkan survey, rata-rata $83,64 \%$ remaja di Indonesia kurang mengkonsumsi buah dan sayur. Padahal berdasarkan data statistik, tingkat ketersediaan buah dan sayur berada di posisi kedua terbanyak sesudah padi-padian. ${ }^{23,24}$

Hasil penelitian selanjutnya menunjukkan bahwa umumnya remaja responden disana tidak memiliki banyak variasi produk olahan susu. Berdasarkan hasil sebagian besar remaja mengkonsumsi susu >1x setiap harinya. Hal tersebut menunjukkan susu merupakan hasil yang terbanyak dan tersering dibandingkan dengan jenis lainnya yaitu keju, yoghurt, dan ice cream. Ketiga jenis produk olahan ini hanya di konsumsi beberapa kali saja setiap bulan. Susu umumnya diminum pada waktu pagi dan malam hari. Hal ini sejalan dengan pola konsumsi susu remaja di daerah bogor. ${ }^{25}$ Susu merupakan produk yang kaya akan zat gizi terutama kalsium. Susu juga sangat berguna untuk remaja yang sedang dalam masa pertumbuhan. Pada penelitian sebelumnya di temukan bahwa kontribusi kalsium terbesar yaitu 3246\% AKG bagi remaja usia 18-19 tahun. Hasil penelitian terebut juga menunjukkan bahwa terdapat hubungan yang nyata antara konsumsi susu dengan status gizi dan densitas tulang remaja. ${ }^{25}$ Roti merupakan makanan jajanan yang paling banyak dikonsumsi. Hal ini sejalan dengan penelitian mengenai pola makan pada remaja di Bitung dimana roti menjadi kegemaran dan dikonsumsi bisa mencapai 4-7 kali sehari. Jajanan lain yang dikonsumsi setiap harinya adalah siomay dan donat. Kedua jenis makanan dikonsumsi lebih dari 1x sehari. Jenis jajanan roti, siomay, donat, dan bakso dikonsumsi setiap hari. Hal ini dapat dikarenakan jajanan tersebut tersedia di daerah sekolah dan sekitar rumah. Rata-rata kandungan energi dan protein yang di dapat dari makanan jajanan tergolong rendah sehingga sumbangan energi dan protein terhadap total konsumsi sehari masih rendah. ${ }^{26}$ Untuk kategori makanan jajanan yang paling jarang adalah pizza. Hal ini di sebabkan pada daerah setempat tidak terdapat jenis makanan seperti itu. Makanan jajanan sering kali di konsumsi remaja untuk mengganti sarapan. Menurut Khomsan, tidak lengkapnya gizi dalam makanan jajanan menyebabkan makanan jajanan tidak dapat menggantikan sarapan pagi / makan siang. Banyaknya konsumsi makanan jajanan hanya akan memberikan rasa kenyang karena padatnya kalori yang 
masuk. Sementara gizi seperti protein, vitamin, dan mineral masih sangat kurang. ${ }^{27}$

Coca-cola cenderung menjadi minuman soft drink terbanyak di konsumsi. Rata-rata remaja mengkonsumsi coca-cola $>1 \mathrm{x}$ setiap hari. Hasil penelitian juga menunjukkan rata-rata seluruh remaja mengkonsumsi minuman berkarbonasi / soft drink lebih dari 1x setiap hari. Hal ini menyebabkan soft drink menjadi kegemaran remaja di Bolaang Mongondow Utara. Soft drink/minuman berkarbonasi memang menjadi favorit yang kian populer, namun asam benzoat dan natrium benzoat yang terkandung di dalamnya dapat menyebabkan penyempitan saraf, kerusakan ginjal,hingga kanker dalam efek jangka panjang. ${ }^{27}$ Tingginya kalori dan gula di dalam soft drink menyebabkan jenis minuman ini juga bertanggung jawab terhadap kelebihan asupan energi yang dapat berujung pada obesitas. Hal ini sejalan dengan penelitian pada remaja SMP di Yogyakarta yang remajanya sering mengkonsumsi softdrink. ${ }^{28}$ Pola makan yang tidak seimbang seperti makan makanan tinggi protein, tinggi lemak, dan tinggi karbohidrat, terutama karbohidrat murni dan disertai asupan serat yang rendah dapat mempengaruhi kadar lipoprotein, trigliserida, dan juga kolestrol dalam darah.

\section{Kecukupan Asupan Zat Gizi}

Berdasarkan hasil penelitian ini, remaja yang belum mencukupi kebutuhan energi sebesar $97,5 \%$. Sisanya $2,5 \%$ remaja memiliki tingkat kecukupan yang baik. Hal ini menunjukkan bahwa asupan energi remaja di daerah penelitian sebagian besar masih belum tercukupi. Hasil ini ditunjang oleh data survei tahun 2014 yang menunjukkan sebesar $18,68 \%$ penduduk Indonesia berada pada tingkat sangat rawan pangan dimana jumlah konsumsi penduduk adalah $<70 \%$ AKG. Hasil riset kesehatan dasar tahun 2013 juga menyebutkan bahwa sebanyak $54,5 \%$ remaja mengkonsumsi energi di bawah kebutuhan. ${ }^{11,23}$ Hasil energi yang kurang dikarenakan jumlah porsi makanan yang dikonsumsi oleh responden masih kurang. Menurut Pedoman Gizi Seimbang, jumlah yang kurang dan juga pola konsumsi yang salah seperti menu makanan yang tidak seimbang dan kurang varian dapat menyebabkan asupan energi tidak tercukupi. ${ }^{18}$ Asupan yang rendah dari yang dibutuhkan akan menyebabkan cadangan energi yang terdapat di dalam tubuh dan disimpan dalam otot terpakai. Keadaan ini jika berlanjut dapat mengakibatkan menurunnya prestasi belajar, juga dapat menyebabkan menurunnya produktivitas kerja. Kekurangan asupan energi ini apabila berlangsung dalam jangka waktu yang cukup lama, akan mengakibatkan menurunnya berat badan dan keadaan kekurangan gizi yang lain. Penurunan berat badan yang berlanjut akan menyebabkan gizi kurang yang akan berakibat terhambatnya proses tumbuh kembang. Dampak lain yang dapat timbul adalah tinggi badan yang tidak mencapai ukuran normal dan mudah terkena penyakit infeksi. Sedangkan konsumsi energi yang berlebihan akan mengakibatkan kenaikan berat badan dan apabila terus berlanjut maka akan menyebabkan kegemukan dan resiko penyakit degeneratif. ${ }^{1,29}$

Energi dalam tubuh dapat timbul karena proses pembakaran makronutrien seperti karbohidrat, protein, dan lemak. Karena itu, agar energi dapat tercukupi perlu mengkonsumsi berbagai macam makanan yang sehat dan seimbang. Makanan seimbang yang di anjurkan adalah makanan yang terdiri atas sumber zat tenaga, misalnya nasi, roti, mie, ubi/singkong, tepung-tepungan, gula, dan sebagainya. Selain itu harus terdiri dari sumber zat pembangun misalnya ikan, telur, daging, susu, kacang, tahu, tempe, dan sebagainya. Makanan juga harus terdiri dari sumber zat pengatur yaitu berbagai jenis sayur-sayuran dan buah-buahan. ${ }^{30,31}$ WHO menganjurkan rata-rata konsumsi energi makanan sehari adalah 10-15\% berasal dari protein, $15-30 \%$ dari lemak, 
dan $55-75 \%$ dari karbohidrat. ${ }^{1}$

Berdasarkan hasil penelitian, remaja memiliki asupan karbohidrat yang sangat kurang. Hal ini dikarenakan umumnya remaja mengkonsumsi sumber karbohidrat yang tidak bervariasi dan dalam jumlah yang sedikit. Jumlah yang sedikit ini sangat disayangkan karena pada periode remaja dibutuhkan asupan yang banyak untuk mengimbangi pertumbuhan dan perkembangan yang pesat. $^{1,7}$ Oleh sebab itu jika sumber karbohidrat tidak sesuai dengan kecukupan, maka kontribusinya untuk energi juga akan tergolong kurang. Asupan energi dan karbohidrat saling berhubungan karena karbohidrat merupakan sumber energi utama terbesar. ${ }^{1}$ Sebesar $75 \%$ total energi diperoleh dari karbohidrat. Dianjurkan untuk mengkonsumsi makanan pokok yang bervariasi setiap harinya. Untuk memenuhi kebutuhan zat gizi selama sehari dianjurkan agar makan secara teratur 3 kali sehari dimulai dengan sarapan atau makan pagi, makan siang dan makan malam. Untuk menghindarkan remaja mengkonsumsi makanan yang tidak sehat dan tidak bergizi maka dianjurkan agar selalu makan bersama keluarga. Sarapan setiap hari juga penting oleh karena mereka sedang tumbuh dan mengalami perkembangan otak yang sangat tergantung pada asupan makanan secara teratur. ${ }^{18}$

Berdasarkan tingkat kecukupan protein, hasil penelitian terbanyak adalah asupan protein yang sangat kurang. Asupan yang sangat kurang disebabkan oleh konsumsi protein yang rendah dan jumlah yang sedikit berdasarkan hasil recall yang dilakukan. Hal ini dapat dilihat dari hasil yang menunjukkan bahan makanan hewani kaya akan protein bermutu tinggi hanya mencakup $18,4 \%$ konsumsi rata-rata penduduk Indonesia. ${ }^{1}$ Ditinjau dari fungsi gizinya, protein berfungsi untuk pertumbuhan maupun pemeliharaan jaringan yang rusak terpakai atau aus. ${ }^{16}$ Proporsi energi yang diperoleh dari protein berkisar antara 10\%-15\% dari total energi makanan. Makanan yang berasal dari protein termasuk lebih mahal dibandingkan dengan makanan bersumber karbohidrat.
Sumber protein adalah ikan, daging sapi, daging ayam, dan kacang-kacangan. Makanan bersumber karbohidrat lebih mudah di dapat bagi sebagian masyarakat. Sumber makanan pokok seperti nasi, singkong, jagung, dan kentang. ${ }^{15-17}$

Di daerah penelitian, mayoritas pekerjaan mengandalkan sektor pertanian sehingga untuk makanan yang bersumber karbohidrat lebih banyak tersedia dan lebih mudah diperoleh ${ }^{20}$ Kekurangan asupan protein juga banyak terdapat pada masyarakat sosio-ekonomi rendah. ${ }^{1}$ Hal ini dapat ditunjang dengan kondisi ekonomi di daerah penelitian yang serupa. ${ }^{14}$ Kekurangan protein akan berdampak terhadap pertumbuhan yang kurang baik, daya tahan tubuh menurun, lebih rentan terhadap penyakit, serta daya kreativitas dan daya kerja merosot. ${ }^{16}$

Konsumsi protein yang baik adalah yang dapat memenuhi kebutuhan asam amino esensial yaitu asam amino yang tidak dapat disintesa didalam tubuh dan harus diperoleh dari makanan. Protein hewani memiliki kualitas yang lebih baik dibanding protein nabati karena komposisi asam amino lebih komplit dan asam amino esensial yang lebih banyak. Berbagai sumber protein hewani dan nabati mempunyai kandungan protein yang berbeda jumlahnya dan komposisi asam amino yang berbeda pula. Oleh karena itu mengonsumsi protein juga dilakukan bervariasi. Dianjurkan konsumsi protein hewani sekitar $30 \%$ dan nabati $70 \%$. Ikan selain sebagai sumber protein juga sumber asam lemak tidak jenuh dan sumber mikronutrien. Konsumsi ikan dianjurkan lebih banyak daripada konsumsi daging. ${ }^{18}$

Konsumsi tempe sekitar 100gram (4potong sedang) per hari cukup untuk mempertahankan tubuh tetap sehat dan kolesterol terkontrol dengan baik. Dianjurkan juga mengkonsumsi daging unggas (misalnya ayam, bebek,burung puyuh, burungdara) selain sebagai sumber protein juga sumber zat besi yang berkualitas sehingga sangat bagus bagi masa pertumbuhan. Namun ada hal yang harus diperhatikan bahwa daging juga 
mengandung kolesterol dalam jumlah yang relatif tinggi, yang bisa memberikan efek tidak baik bagi kesehatan. ${ }^{18}$

Hasil analisis recall juga menunjukkan bahwa asupan lemak kategori baik, sedang, dan kurang masing-masing sebesar 7,5\%. Asupan lemak yang masih sangat kurang memiliki presentase lebih besar yaitu $77,5 \%$. Hal ini menunjukkan bahwa jumlah remaja dengan tingkat asupan lemak yang cukup sama banyak dengan jumlah remaja dengan tingkat asupan lemak sedang. Jumlah terbanyak di dominasi oleh remaja dengan tingkat asupan lemak sangat kurang.

Konsumsi banyak lemak terutama yang mengandung banyak asam lemak jenuh rantai panjang, dapat meningkatkan kadar kolestrol darah. Kolestrol darah yang meninggi dikaitkan dengan meningkatnya prevalensi penyakit kardiovaskular, terutama hipertensi. Pada orang yang obesitas juga terdapat peningkatan kadar kolestrol darah. ${ }^{16}$

Salah satu faktor menyebabkan perubahan pola makan yaitu pengetahuan dan kesadaran akan pentingnya asupan gizi. Akan tetapi masyarakat pada umumnya beranggapan bahwa telah tercukupinya asupan kebutuhan pada saat merasa kenyang. Padahal saat merasa kenyang, belum tentu asupan zat gizi yang dibutuhkan telah tercukupi. Anggapan tersebut kurang tepat sebab dalam pemilihan bahan makanan perlu mendapat perhatian khusus. Dalam pemilihan makanan, tidak hanya melihat kuantitasnya tetapi juga nilai gizi dari makanan tersebut.

\section{SIMPULAN}

Berdasarkan hasil penelitian ini maka dapat disimpulkan bahwa :

1. Perlu diberikan sosialisasi terkait kebutuhan tubuh akan zat makro dan mikronutrien yang diperlukan kepada remaja di daerah Bolaang Mongondow Utara.

2. Perlu kepedulian keluarga dan lingkungan sekitar untuk dapat lebih memperhatikan kebutuhan pola asupan yang baik dan seimbang.

3. Perlu dilakukan penelitian lebih lanjut mengenai analisa faktor yang mempengaruhi pola asupan makanan.

\section{SARAN}

Berdasarkan hasil penelitian, maka disarankan untuk:

1. Perlu diberikan sosialisasi terkait kebutuhan tubuh akan zat makro dan mikronutrien yang diperlukan kepada remaja di daerah Bolaang Mongondow Utara.

2. Perlu kepedulian keluarga dan lingkungan sekitar untuk dapat lebih memperhatikan kebutuhan pola asupan yang baik dan seimbang.

3. Perlu dilakukan penelitian lebih lanjut mengenai analisa faktor yang memengaruhi pola asupan makanan.

\section{DAFTAR PUSTAKA}

1. Almatsier S. Prinsip Dasar Ilmu Gizi. Jakarta: PT Gramedia Pustaka Utama, 2010.

2. Kementerian Kesehatan RI Direktorat Bina Gizi, Direktorat Jenderal Bina Gizi dan KIA. Naskah Akademik Pedoman Gizi Seimbang. Direktorat Bina Gizi. Jakarta, 2013.

3. Almatsier, Sunita. Editor. Penuntun Diet Instalasi Gizi RS Cipto Mangunkusumo dan Asosiasi Dietisien Indonesia. PT. Gramedia Pustaka Utama. Jakarta, 2007.

4. Sediaoetama A. Ilmu Gizi Jilid II Jakarta: PT Dian Rakyat; 2012.

5. Azwar, A. Kecenderungan Masalah Gizi Dan Tantangan Di Masa Datang. Disamping dalam advokasi perbaikan gizi menuju kadarzi; 2004.

6. Yang $Z$, et $\mathbf{l}$. Nutrition in pregnancy and early childhood and associations with obesity in developing countries. 9 Jan 2013. Diunduh dari: http://www.ncbi.nlm.nih.gov/m/pubm ed/23167588/?i=6\&from $=/ 22742617 /$ related Diakses pada: September 2016.

7. Almatsier S, Soetardjo S, Soekarti M. Gizi Seimbang Dalam Daur Kehidupan. Jakarta: PT Gramedia Pustaka Utama; 2011. 
8. Story M. Nutritional requirements during adolescence. In: McAnarney ER, Kreipe RE, Orr DE, Comerci GD, eds. Textbook of adolescent medicine. Philadelphia: WB Saunders, 1992;75-84.

9. Fatmah. Pengalaman Negara Lain Dalam Perbaikan Gizi Remaja Sekolah Menengah [skripsi]. Jakarta: Universitas Indonesia; 2010.

10.Suryaputra K, Nadhiroh SR. Perbedaan Pola Makan Dan Aktivitas Fisik Antara Remaja Obesitas Dengan Non Obesitas. 2012. Diunduh dari: http://journal.ui.ac.id/index.php/healt h/article/viewFile/1301/1190 Diakses pada: September 2016.

11. Anonim. Riset Kesehatan Dasar 2013. Badan Penelitian dan Pengembangan Kesehatan. Kementrian Kesehatan Republik Indonesia Tahun 2013.

12.Mokolensang OG, Manampiring AE, Fatimawali. Hubungan Pola Makan Dan Obesitas Pada Remaja Di Kota Bitung [skripsi]. Manado: Universitas Sam Ratulangi; 2015.

13.Anonim. Wikipedia. Kabupaten Bolaang Mongondow Utara. 2016. Di kunjungi

laman:https://id.wikipedia.org/wiki/K abupaten_Bolaang_Mongondow_Utar a Diakses: September 2016.

14.Kementrian Dalam Negeri Republik Indonesia. Profil Kabupaten Bolaang Mongondow Utara 2011. Diunduh dari: http://www.kemendagri.go.id/ pages/profil-daerah/kabupaten/id/71/ name/sulawesi-utara/detail/7108/ bolaang-mongondow-utara Diakses pada: September 2016

15.Supariasa, IDN, Bakri B, Fajar I. Penilaian Status Gizi. Jakarta: Buku Kedokteran EGC. 2002.

16. Sulistyoningsih,H. Gizi Untuk Kesehatan Ibu dan Anak. Yogyakarta: Graha Heru. 2011.

17.Amelia S. Permenkes Tentang Angka Kecukupan Gizi. Jumat, September 2014. Diunduh dari: http://gizi.depkes.go.id/permenkestentang-angka-kecukupan-gizi

18. Kementrian Kesehatan RI. Pedoman Gizi Seimbang. 2014. Diunduh dari: http://gizi.depkes.go.id/download/Ped oman\%20Gizi/PGS\%20Ok.pdf
Diakses Pada: September 2016

19.Gunanti, I.R. Kebiasaan Makan, Konsumsi Zat Gizi, Status Gizi Anak Pra Sekolah dan Keterlibatan Ibu dalam Kegiatan Sosial di Luar Rumah. Pusat Penelitian dan Pengembangan Gizi Lembaga Penelitian Universitas Airlangga. 2006.

20.Anonim. Kabupaten Bolaang Mongondow dalam Angka. Badan Perencanaan Pembangunan, Penanaman Modal, dan Statistik Daerah Kabupaten Bolaang Mongondow. 2011.

21.Kementrian Kesehatan Republik Indonesia. Studi Diet Total. 2014. Diunduh dari: http://labdata.litbang.depkes.go.id/rise t-badan-litbangkes/menuriskesnas/menu-rikus/392-rikus-sdt2014 Diakses pada: September 2016

22.Gustiara I. Konsumsi Sayur dan Buah pada Siswa SMA N 1 Pekanbaru. 2013.

23.Anonim. Data Statistik Ketahanan Pangan 2014. Badan Ketahanan Pangan Nasional. Kementrian Pertanian Republik Indonesia. 2014.

24. Anonim. Survei Sosial Ekonomi Nasional. Badan Pusat Statistik Nasional. 2013.

25.Karlina. Hubungan Konsumsi Susu dan Kebiasaan Olahraga dengan Status Gizi dan Densitas Tulang Remaja di Asrama Tingkat Persiapan Bersama (TPB) Institut Pertanian Bogor. 2011.

26.Hapsari R. Kontribusi Makanan Jajanan Terhadap Tingkat Kecukupan Asupan Energi dan Protein Pada Anak Sekolah Yang Mendapat PMT-AS di SD N 1 Kota Surakarta [skripsi]. Universitas Muhammadiyah Surakarta. 2013.

27.Khomsan,Ali. Pangan dan Gizi Untuk Kesehatan. 2003.

28.Saputri R. Hubungan Konsumsi Soft Drink Dengan Kejadian Obesitas Pada Anak Usia Remaja di SMP Budi Mulia Dua Yogyakarta [skripsi]. Universitas Muhammadiyah Surakarta; 2013.

29.Masyarakat DGdK. Gizi dan Kesehatan Masyarakat. Jakarta: Raja Grafindo Persada: 2010.

30.Kartasapoetra, G. Marsetyo, H. Ilmu Gizi (Korelasi Gizi dan Kesehatan dan Produktifitas Kerja). Rineka Cipta. Jakarta. 2003.

31.Santoso, Soegeng, Annel S. Kesehatan dan Gizi. Rineka Cipta: Jakarta. 2004. 
Mokoginta, Budiarso, Manampiring: Gambaran pola asupan... 